effect and actively search for it, particularly as acceptable alternative hypotensive agents are available. It must be borne in mind that in Sainsbury's 1967 inquiry into consummated suicide $28^{\circ}$ of the patients had been receiving hypotensive agents, including methyldopa. ${ }^{3}$ Therefore a previous history of mental depression must continue to be accepted as a contraindication to the exhibition of methyldopa. ${ }^{3} 7$

It is interesting to note that in the clinicopathological conference reported in the same issue ( 1 September, p. 480) depression as a side effect of methyldopa was not considered, though the patient became depressed while on methyldopa. Senile melancholia is a "common early manifestation of lurking neoplasia," but it would have been reasonable to exclude methyldopa, if not as the cause, at least as a precipitating or exacerbating agent.-I am, etc.,

D. PARIENTE Napsbury Hospital,
nr. St. Albans, Hert 1 Beck, A. T., Depression. London, Staples Press,

Goldberg, D. P., The Detection of Psychiatric Illness by Questionnaire. London, Oxford University Press, 1972 .

edn. London, Baillière, Tindall and Cassell, edn.

Meyers, F. H., Jawetz, E., and Goldfein, A., Review of Medical Pharmacology, 3rd edn. Los Aetos, California, Lange Medical Publications, 1972. The Pharmacological Basis of Therapeutics, ed.
L. S. Goodman and A. Gilman, 4th edn. New York, Macmillan, 1970.

6 Adverse Drug Reaction Bulletin, 1968, nos. 8-13,

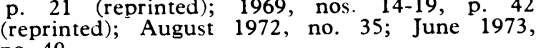

Martindale's Extra Pharmacopoeia,

26 th edn.

8 Side Effects of Drugs, vol. 6, ed. L. Meyler and A. Herxheimer. Amsterdam, Excerpta Medica Foundation, 1968.

\section{Treatment of the "Irremediable" Elderly Patient}

SIR,-I would like to add one more item to Dr. Bernard Isaacs's (8 September, p. 526) list of investigations which no elderly person should be denied-a hearing test by voice and audiometer. I believe that no assessment of the elderly patient, whether by a general practitioner or a consultant geriatrician, is complete unless this is done. Hearing loss in the elderly is exceedingly common, rem diable, and frequently overlooked. The e.derly persun is not only more confused by p:oblems of corimmunication but also less able to co-operate with those who are responsible for his medical or social care.-I am, etc.,

Romford, Essex

R. BEAVER

\section{F.D.P. Levels in Different Types of Intravascular Haemolysis}

SIR,-The findings reported by Dr. S. D. Slater and others (1 September, p. 471) are not open to such simple interpretation as the authors imply, though one cannot at this stage deny that their ultimate conclusion is correct-namely, that fibrinogen-fibrin degradation product (F.D.P.) levels are raised in microangiopathic haemolytic anaemia but not when there is haemolysis due to a prosthetic valve. Two points cannot be ignored: the first that in microangiopathic haemolytic anaemia there is inevitably impairment of renal function so that, in fact, some elevation of the F.D.P. level will be due to poor renal excretion of F.D.P., and secondly, that in any haemolytic anaemia of long standing reticuloendothelial hyperplasia may accoun for removal of fibrin by an alternative route.

In order to prove that microangiopathic haemolytic anaemia is associated with increased production of F.D.P., radiofibrinogen catabolism studies must be performed. 1 . think it is important to emphasize that fibrin can persist in vessels only when fibrinolysis is impaired as a result of prior damage to vascular endothelium (usually by immunological mechanisms). What is reauired is a study of fibrinolysis in microang:opathic haemolytic anaemia as compared with other types of intravascular haemolysis.-I am etc.

\section{Department of Medicine,}

E. N. WARDLE Nowal Victoria Infirmary,

1 Wardle, E. N., Quarterly fournal of Medicine,

\section{Late Advertising of Hospital Posts}

SIR,-In view of the recent correspondence in your columns about junior medical staff appointments in hospital, the following might be of interest.

Recently, a senior house officer post in our hospital group was advertised. Four applicants were asked to attend for interview, of whom not one turned up on the day, and none of whom either wrote or telephoned to say that he would not be attending. Comment is superfluous.-I am, etc.,

Manchester

T. D. CulberT

\section{Ileostomy and Colostomy}

SIR,-A recently published news item on "Ileostomy and Colostomy" caught my eye having had the latter condition for the past 12 years. On duly obtaining a copy of the booklet on colostomy ${ }^{1}$ to which the news item drew attention I was quite astonished to find that the sole method recommended for controlling disposal of the excreta was the use of various forms of disposable plastic pouches.

Upon two occasions in the 12 years, because of two sharp attacks of enteritis, have I had to resort to such fussy and unpleasant methods; otherwise I have managed with a simple dressing pad maintained in position during the day by a simple belt (lightweight Aertex type in warm weather) with a zipped panel for ease of access, and a roll-on elasticized belt for nightwear. I am fully active and travel considerably on my professional duties but, like the ulcerative colitis patient, I do attempt to maintain geographical knowledge of available toile facilities in the vicinity of my peregrinations. Material for a spare pad is carried as a "first field dressing" in hip or poacher's pocket and with this can be incorporated prepared stick-on pouch for complete ease of mind in the potentially difficult situation.

To refrain from mentioning this simple method, which must be in common usage, in a booklet entitled "The Care of Your
Colostomy" seems quite incredible and implies a life-time of unnecessary burden upon the unfortunate patient who is so advised.- I am, etc.,

Crowborough, Sussex

R. L. MACPHERSON

1 Goligher, J. C., and Pollard, M., The Care of Your Colostomy, 2nd edn. London, Baillière Tindall, 1973.

\section{Sick Sinus Syndrome}

SIR,-A recent timely leading article on the sick sinus syndrome (23 June, p. 677) contains the observation that "symptomatic sinus node disease. . . implies disease of the conducting tissue bevond the sinus node." This contention cannot go unchallenged.

Electrophysiological studies of the sinoatrial node in man have not yet proved possible as adequate recording of sinoatrial nodal action potentials is not satisfactory unless the node itself is impaled. ${ }^{1}$ Therefore the primary generator function of the $P$ cells of the sinoatrial node and the existence of exit and/ or entrance blockade between the $P$ cells, transitional cells, and working myocardial cells which make up the sinoatrial node ${ }^{2}$ can at present only be inferred in man. Major changes in heart rate are produced by suppression of one pacemaker site within the sinoatrial node and dominance of another. ${ }^{3}$ The complex interplay demonstrated in animals between the structures which compose the sinoatrial node suggest a converse aetiological hypothesis in this entity to that stated in your leading article.-I am, etc.,

J. H. HORGAN

Medical College of Virginia,

Richmond, Virginia

Ferrer, M. I., Circulation, 1973, 67, 635.

James. T. N., Sherf, L., Fine, G., and Morales, A. R., Circulation, 1966, 34, 139. Hoffman, B. F., and Cranefield, P. F., Electrophysiology of, the Heart, p. 127. New York,
McGraw-Hill, 1960 .

\section{Antibiotics and Endotoxic Shock}

SIR,-The letter from Professor A. Z. Shafei and Mr. W. S. Luka (7 July, p. 50) reporting the effectiveness of doxycycline, a bacteriostatic antibiotic, in the treatment of enteric fever and similar reports from Egypt on co-trimoxazole ${ }^{1}$ provide practical confirmation of the views expressed many years ago by Reilly and his colleagues ${ }^{2}$ at the Claude Bernard Hospital in Paris. They suggested that the initial failure to reduce the overall mortality from enteric fever following the introduction of chloramphenicol was due to the practice of beginning treatment with a "loading dose," which, by its very effectiveness in destroying typhoid bacilli, released a dose of endotoxin which, added to that already circulating in the blood stream, could prove fatal. He confirmed his thesis in a series of carefully conducted experiments on laboratory animals and at the same time showed that pretreatment with chlorpromazine in a dosage of $1 \mathrm{mg} / \mathrm{kg}$ body weight effectively protected animals against the endotoxin released from typhoid bacilli destroyed by chloramphenicol.

Similar reasoning could be applied to the case of fatal endotoxic shock originating in the biliary tract following transhepatic cholangiography reported by $\mathrm{Mr}$. M. R. B. 